\title{
PREFACE
}

This book deals with two remarkable events-the worldwide transformations of the Jews in the modern age and the revival of the ancient Hebrew language. It is a book about social and cultural history addressed not only to the professional historian, and a book about Jews addressed not only to Jewish readers. It tries to rethink a wide field of cultural phenomena and present the main ideas to the intelligent reader, or, better, present a "family picture" of related and contiguous ideas. Many names and details are mentioned, which may not all be familiar to the uninitiated; their function is to provide some concrete texture for this dramatic story, but the focus is on the story itself.

The last hundred, or hundred and twenty, years have witnessed a radical transformation of Western civilization, and of humanity as a whole. The transformations of the Jews were, essentially, part of that process. They manifested the transitions from a "medieval" to a modern, Western-type civilization; the tensions between cultural tradition and modem sensibility and between ethnicity and cosmopolitanism; the rise of a lower-class population to the centers of sophisticated culture; the crucial role of language in group identity; processes of urbanization, immigration, secularization, democratization, mass education; the new centrality of science and communications; and so on. But among the Jews, the same processes came later than among the established nations of Europe, were more rapid and drastic, and enveloped wider circles. The transformations of the Jews often clashed with other trends-notably, the totalitarian regimes-that emerged in the same radical age; and they were heavily "overdetermined" (to use Freud's term) by the peculiar characteristics of Jewish tradition, mentality, and destiny.

The very fact that it was a nation without its own territory, with a slanted selection of professions, a people on the move with no certainty about its moorings, with a penchant for constantly asking (or actively refraining from asking) about its own identity-all this shifted the problem from the political to the 
ideological and cultural domain. A culture of an extraterritorial caste had to survive in a world of politically monolingual, centralized nations, and change or melt into them. It was a small but sufficiently significant group, tainted by history, carrying several private languages around the globe, and producing in a short time a centrifugal explosion of contradictory tendencies, which appeared like a whirling, restless kaleidoscope, enclosed in its own orbit. All that made the transformations of the Jews not just a more intense example of general tendencies but a very peculiar case indeed. And, from the internal point of view, it totally changed the nature of Jewish history.

The book consists of two concentric essays. The first examines the nature of what we may call the Modern Jewish Revolution. This revolution, emerging from the internal responses of Jews to the challenges of history, brought about the total transformation of the Jewish people in the century of 1882-1982. The period is overshadowed by dramatic events - the migrations of the Jews, the Holocaust in Europe, and the creation of the State of Israel are the most obvious examples-yet I analyze here not the well-known external history but the internal responses in culture and consciousness. Such responses, implemented by many individuals and in many directions, resulted, on the one hand, in the creation of a modern, secular Jewish literature and society and a Jewish State and, on the other hand, in assimilation to other languages and important contributions made by "Jews" and their descendants to general culture and science. In this essay, I draw the map as a whole, including both its wings, but focus primarily on the internal culture, leaving the external ("assimilated") direction for another study. Special attention is given here to the creation of a new Hebrew society in Palestine/EretzIsrael, in the context of this revolution.

Part II is a close investigation of one aspect of that revolution: the almost "miraculous" revival of the Hebrew language and its emergence as the base language of a new, Hebrew society. Indeed, of all the cultural creations of this age, what remains is a rich secular Yiddish and Hebrew literature, as well as a partly "Jewish" literature in other languages (Bruno Schulz, Joseph Roth, Philip Roth, Saul Bellow, and many others); but what continues is the living Hebrew literature and culture of Israel, based on the Hebrew revival. Language was at the center of interest in modern philosophy, literary criticism, human sciences, and politics; Modernism in all the arts was focused on a revolution in the "languages" of art; in the Hebrew case too there was a sense that an entirely new language will create a "New Man" and a new society. But here the upheaval was radical, changing not just the secondary language of ideology but the natural language of society itself. A recent sociological book describes Israel as the result of "an ideological trend that created a society that became a State" (Horowitz and Lissak 1990: 9). It would be even more correct to say: "an ideology that created a language that forged a society that became a State." And each of these four stages was not automatically entailed in its predecessor but required an immense effort at transcending its boundaries.

While Part I draws a rather general and comprehensive map, Part II 
provides a detailed analytical study of one historical phenomenon in all its ramifications. It shows the language revival to be not a magic trick of one stubborn idealist (the mythologized Eliezer Ben-Yehuda) but a highly complex interaction of historical, social, ideological, psychological, and linguistic clusters of facts.

The subject of this book is immense; many scholars have investigated various aspects of the history of this period, filled with events, trends, and documents. I shall rely on the relevant scholarship (without burdening the reader with endless details and footnotes), but my purpose is different: I intend to present an overall conception of the problem as I see it. This is basically a phenomenological essay: I am concerned here not with the multitudes of numbers, witness accounts, and individual biographies, but with the understanding of the interwoven, complex phenomena, the general tendencies that cut across the many individual ideologies, facts, and persons. The book deals with the relations between ideological trends (explicit and implicit), semiotics of culture, individual psychology, and changes in history. The boundaries between literary scholarship, history of ideas, sociolinguistics, and analysis of a society cannot be preserved in such a framework. In other words, this is an essay that tries to rethink aloud many facts known in isolation; the gloves of disciplinary methodologies are dropped.

In recent years, there has been a strong positivist trend in Jewish historiography, encouraged by the multitude of facts and stories waiting to be uncovered and the conventions of academic discourse. No doubt, valuable studies have been published and our knowledge has increased immensely. But no matter how many facts we uncover, we still have to erect a construct to justify our selection and explain the historical trends. This book tries to erect the construct itself: it provides a network of generalizations, which may be seen as hypotheses, to be falsified or further refined by others.

The essay on the revival of the Hebrew language (Part II) deals primarily with its sociocultural and ideological aspects. For the most part, I have not pursued any narrow linguistic analysis - and in those passages where I have, the reader can understand the point without knowing the language. This part is accompanied by a selection of telling documents, Sources on the Hebrew Language Revival, written by salient figures of the period and translated from Hebrew by Barbara Harshav.

Another, formerly central and now almost extinct, creation of the revolutionary period was the worldwide literature and culture of Yiddish, which I treated in my book The Meaning of Yiddish (Harshav 1990a). In that study, I first outlined some of the conceptions developed in the present book.

The other side of the coin is the massive influx of Jews into the national cultures of various countries and the question of a possible "Jewish" contribution to general culture and science in the modern age. I discussed this question in lectures titled "The Jewishness of the "Non-Jewish Jew'" (referring to Isaac Deutscher's term) and "The 'Jewish Discourse' Hypothesis." Though raised in general terms in Part I, this topic is much too complex to be dealt with properly here; it deserves a separate study.

Strange as it may sound, though this book deals with quite recent trends and 
events, the revolutionary spirit and the period of transformations of the Jews are over. The urbanization and assimilation of European Jewry, and the role they played in German, Russian, Polish, and other cultures in the twentieth century, are gone with the Jews themselves. Only in America did a major center of assimilated Jewry survive. Likewise, the exuberant flourishing of Jewish secular ideologies and social and cultural institutions, including a rich literature in Hebrew and Yiddish written around the world, is gone too. A secular Jewish culture and society survived only in the Hebrew State of Israel.

All that remains is an interesting chapter of history and a library of fascinating texts.

And a point of caution: some of the issues discussed here in historical perspective are still alive in the present. In this book, however, I intend to describe and not to prescribe. In the beginnings of Jewish emancipation, equality was granted to the individual and not to Jews as a group or cultural entity. Now that both possibilities are open in democratic societies, it is up to the individual to decide whether he wants to shed his Jewish identity altogether, embrace ultra-Orthodox religion, or act on anything in between. I come not to judge but to show what transpired in this turbulent, perhaps transitional, but creative century. I believe it is one of the interesting periods in the history of cultural change.

This is especially true for the second part of the book. The current political situation, including various actions of Israeli governments, often obstructs the historical perspective. Nevertheless, we must recognize that the creation of Israel was the greatest internal response that changed the nature of Jewish history as it subsisted in the last two thousand years, and it may yet provide the only base for the continuation of a viable, secular Jewish culture in the future. The revival of the Hebrew language enabled it all-and it is a fascinating story in its own right.

\section{A NOTE ON TERMINOLOGY AND SPELLING}

The book describes a movement in Jewish history from the past into the future, hence the use of such terms as intrinsic versus extrinsic trends, as seen from the internal perspective; they are meant not in a judgmental but in a purely descriptive sense. Similarly, the term Diaspora (dispersion) - as opposed to Eretz-Israel (Palestine) - is not meant to impose on the description a Zionist ideology but simply to refer to the existential situation of the Jewish minority throughout the world (actually, the traditional and Zionist term for "Diaspora" is Galut, "Exile"). The term Eretz-Israel ("The Land of Israel") is the traditional Jewish name for Palestine; since the label "Palestine" (which used to be a Zionist name for that country) became Arabized, I often resort to the Hebrew term when referring to the land before the creation of the State of Israel in 1948. However, the new Jewish society that emerged in Eretz-Israel before 1948 is called Yishuv (a loaded word, meaning "a stable settlement," as opposed to the "Exile" of the "Wandering Jew") or the 
"new Yishuv," as opposed to the "old Yishuv," the Orthodox community that lived or settled in the cities of Palestine throughout the ages and hardly participated in the Zionist revival.

A frequently used term in this book is Aliya (pl. Aliyot). Aliya means immigration to the Holy Land, or to Israel (literally, "climbing up a mountain," from the image of ascending Mount Zion; the opposite, leaving Israel, is called yerida, "descent"). When qualified by a number, it refers to the waves of modern, Zionist immigration to Eretz-Israel/Palestine, each delimited in a specific period and characterized by a dominant group of people and source of origin. In the period of each Aliya, people of various types and origin arrived, but the Aliya is known for the group that gave its special tone.

The First Aliya (1881-1903) came after the pogroms in Russia in 1881-82; it consisted mainly of Russian and Romanian Jews, who built new, Jewish agricultural settlements, with private farmers.

The Second Aliya (1904-1914) began in the wake of the Kishinev and Homel pogroms in 1903 and the failed Russian Revolution of 1905, and brought intellectual youth from the Russian Empire (especially from Poland and Byelorussia) who created the labor movement and the first collectives in Eretz-Israel.

The Third Aliya (1919-1923) came after the Balfour declaration of 1917, the two Russian Revolutions, the Russian Civil War of 1918-1922, and the exterminating pogroms in Ukraine in 1919. They brought a more massive influx of Socialist-oriented youth from Russia (especially Ukraine) and the former AustroHungary (Galicia), who built roads and established the kibbutz movement.

The Fourth Aliya (1924-1928) brought middle-class families, especially from Poland, who built the cities, primarily Tel Aviv.

The Fifth Aliya (1929-1939) brought German Jews in the time of Hitler.

All passages quoted in this book have been translated by its author, unless excerpted from sources in English (as indicated in the list of References).

The transcription of Hebrew words and names is straightforward, assigning a fixed letter to each sound, and not attempting any adaptation to English spelling. For some sounds, two or three letters were used: sh (as in English), ts (like zz in Pizza), tsh (like ch in chair), kh (like ch in chutzpah). But whenever a Hebrew het is distinguished from a khaf, the first is represented by $\mathbf{h}$ and the second by $\mathbf{k h}$. Vowels are used as in Italian, German, and other European languages. The same vowels appear in diphthongs: oy (like oy in boy), ay (like uy in guy), ey (like ay in day).

For the sake of uniformity, I have transcribed names directly from the Hebrew or Yiddish, irrespective of the various spellings they have been represented by in the past. Hence: Berditshevski rather than the German Berditschewski, the Polish Berdyczewski, or the Anglicized Berdichevsky; Dubnov rather than Dubnow; Tsemakh and not the German Zemach (which would sound in English like zebra); Isvi and not $Z$ vi or $Z w i$. 
But in several cases exceptions have been made: we use the accepted (German) spelling of Eretz-Israel (for what should be Erets); and Yitzhak rather than the normative Yitshak (because the combination sh would make it read Yit-shak). We also preserved the author's own spelling of Jabotinsky instead of the proper transcription Zhabotinski, for readers who know this name might otherwise not be able to identify it.

In representations of sounds the stressed syllable of a word is in capital letters wherever relevant. For example, the Israeli pronunciation daVID is officially stressed on the last syllable, but affectionately on the first: DAvid.

\section{ACKNOWLEDGMENTS}

Parts I and II of this book are based on two earlier essays published in Hebrew. The first began as a lecture at Harvard University in December 1980, titled "1881-A Watershed in the History of Jewish Culture and Consciousness," and continued as a lecture at a conference on "Culture and Society in Eretz-Israel" at the Open University at Tel Aviv. It was published in a book edited by Nurith Gertz (Harshav 1988). The second essay was commissioned by the most stimulating of editors, Nitza Drory-Peremen, for a new Israeli intellectual periodical, Alpayim (Harshav 1990b). I would like to thank Robert B. Alter, Nitza Drory, Itamar Even-Zohar, Nurith Gertz, Irving Howe, Chana Kronfeld, Yakov Shavit, and many others with whom I exchanged ideas on these issues. I am grateful to Hagi and Vered Kenaan for compiling the index. Barbara Harshav, as before, was my first and indispensable reader and editor. 